\title{
Sustainable Fashion, Investasi pada Produk Fashion yang Berkualitas untuk Mengurangi Limbah Fashion yang Menumpuk
}

\author{
Shafira Qiddist Sayyida ${ }^{1}$, Marina Wardaya ${ }^{2 *}$ \\ 1,2 Visual Communication Design, Fakultas Industri Kreatif, Universitas Ciputra \\ Citraland CBD Boulevard, Surabaya \\ *Penulis korespondensi; Email: marina.wardaya@ciputra.ac.id
}

\begin{abstract}
Abstrak
Setiap manusia memiliki kekhawatiran akan masa depan. Kekhawatiran tersebut diantaranya adalah tentang lingkungan yang meliputi limbah, efek rumah kaca, pencemaran, dan lainnya. Industri fashion mengambil peran cukup banyak dalam meningkatnya kerusakan lingkungan oleh limbah yang dihasilkan. Nyatanya kesadaran masyarakat dalam perilaku belanja cukup memegang peran penting sebagai awal untuk mengurangi limbah fashion. Kebiasaan membeli produk yang cepat rusak merupakan salah satu hal yang menyebabkan menumpuknya limbah fashion yang ada di dunia. Membeli produk fashion dengan kualitas yang baik akan mengurangi laju konsumsi sehingga dapat mengurangi limbah fashion yang ada. Hal tersebut merupakan langkah kecil untuk sustainable fashion. Metode penelitian yang digunakan pada literatur ini adalah kajian pustaka, yaitu dengan mengumpulkan sumber literatur yang kuat untuk mendukung dan mencari kesimpulan akhir. Sumber yang digunakan merupakan jurnal nasional, jurnal internasional, dan juga buku. Hasil akhir penelitian ini menyimpulkan bahwa perilaku belanja masyarakat cukup berpengaruh pada sedikit-banyaknya limbah yang dihasilkan dan juga berpengaruh pada laju konsumsi. Menanamkan kesadaran pada masyarakat untuk investasi dengan membeli prioduk berkualitas dapat membantu mengurangi limbah fashion yang semakin hari semakin meningkat.
\end{abstract}

Kata kunci: Mode, berkelanjutan, lingkungan, belanja.

\begin{abstract}
Every human being has concerns about the future. These concerns include the environment which includes waste, greenhouse effects, pollution, and others. The fashion industry takes a considerable role in raising environmental damage by the waste produced. Public awareness in shopping behavior plays an important role as a start to reduce fashion waste. The habit of buying products that quickly break down is one of the things that causes the accumulation of fashion waste in the world. Buying fashion products with good quality will reduce the rate of consumption to reduce existing fashion waste. It is a small step for sustainable fashion. The research method used in this article is by literature study, which is by collecting strong sources of literature to support and seek the conclusion. The sources used are national and international journals, as well as books. The result of this study concluded that people's spending behavior is quite influential on the amount of waste produced and affects the rate of consumption. Instilling awareness in the community for investment by buying quality products can help reduce the waste of fashion that is increasing every day.
\end{abstract}

Keywords: Fashion, sustainability, environment, shopping.

\section{Pendahuluan}

Seluruh umat manusia memiliki alasan yang kuat untuk khawatir terhadap masa depan, Salah satu penyebabnya adalah dunia yang tidak stabil, sehingga umat manusia cukup khawatir tentang dunia sebagai rumah yang semakin lama semakin tidak sehat. Ancaman seperti gizi buruk, efek rumah kaca, terorisme, penyakit dan banyak hal lain yang menuntut manusia untuk melakukan hal demi kebaikan Bersama (Margolin, 2007).
Selama ini, desain memegang peran penting dalam kehidupan manusia. Hal itu disebabkan oleh banyaknya disiplin ilmu yang dipelajari dan dikuasai oleh desainer, diantaranya adalah komunikasi visual, produk, pengembangan perangkat lunak dan masih banyak lagi. Hal ini cukup penting untuk diulas karena saat ini kebanyakan seorang desainer hanya membatasi dirinya sebagai profesi, padahal banyak hal yang lebih luas diantara itu (Margolin, 2007). 
Salah satu hal yang berada pada ranah seorang desainer adalah mendesain produk, desainer tidak hanya bisa mendesain sebuah produk, namun juga bisa menentuka material, kualitas dan juga semua yang berhubungan dengan produk yang dibuatnya. Dalam literatur ini, hal spesifik yang dibahas adalah sustainable fashion, yaitu kualitas produk fashion, perilaku masyarakat dalam membeli produk, dan hubungannya dengan lingkungan sekitar. Hal ini penting untuk dibahas karena kesadaran masyarakat akan perilaku belanja yang dapat berimbas terhadap menumpuknya limbah fashion hingga meningkatkan efek rumah kaca. Perilaku belanja masyarakat pada kualitas produk tertentu juga berpengaruh. Topik ini dianggap penting karena nyatanya kebiasaan belanja masyarakat juga berpengaruh pada lingkungan, yaitu tempat tinggal kita.

\section{Metode Penelitian}

Metode yang digunakan adalah Kajian Pustaka. Kriteria jurnal yang digunakan adalah jurnal dengan DOI dan harus berhubungan dengan topik yang akan dibahas, tidak memiliki rentang waktu, sehingga bisa menggunakan jurnal lama ataupun jurnal baru.Jurnal yang diperoleh berhubungan dengan kata kunci design, fashion, sustainable, dan environment. Tidak hanya jurnal, literatur ini juga menggunakan buku sebagai sumber.

\section{Pembahasan}

\section{Sustainable}

Saat ini isu sustainable (berkelanjutan) terjadi pada berbagai bidang. Sustainable Development (pembangunan berkelanjutan) merupakan usaha untuk mencukupi kebutuhan masyarakat era ini namun tetap memperhatikan dan memedulikan masyarakat di era yang akan datang. Pembangunan berkelanjutan juga memiliki beberapa prinsip, diantaranya adalah keberlanjutan ekonomi, keberlanjutan sosial, keberlanjutan ekologi, dan minimalisasi resika dan bahaya kesehatan manusia (Priyoga, 2010).

\section{Sustainable Design}

Sustainable Development dapat dijabarkan menjadi beberapa konsep yang lebih spesifik, salah satunya adalah sustainable design (desain berkelanjutan). Sustainable design adalah desain yang yang diciptakan untuk mengatasi keadaan yang terjadi saat ini dengan tujuan mengurangi dampak negatif yang terjadi pada lingkungan, Kesehatan, dan hal lainnya (Priyoga, 2010).
Desainer merupakan salah satu diantara orangorang yang cukup penting yang kontribusi positifnya dapat membangun dunia yang lebih baik. Karena segala yang ada di lingkungan kita adalah sebuah 'desain'. Tanpa desainer, perusahaan tidak memiliki hal untuk diproduksi ataupun layanan untuk ditawarkan. Terlebih lagi, saat ini, telah banyak sumber daya di internet yang cukup melimpah yang dapat menjadi kekuatan untuk seorang desainer (Margolin, 2007).

Semakin lama, perubahan dunia semakin cepat. Apabila seorang desainer ingin ambil suara dalam perubahan untuk masa depan, maka mereka harus terlibat secara langsung. Salah satu metode awal yang dapat dilakukan adalah dengan memprediksi masa depan yang didasarkan pada prediksi spekulatif. Dengan begitu, desainer dapat terlibat dalam sustainable design. Cara lain yang dapat dicoba adalah memecahkan maslah dengan mencoba metode desain yang baru, atau melibatkan konsumen dalam proses transformasi berkelanjutan (Hemmings, 2008; Margolin, 2007)

Desainer mampu menciptakan perubahan yang lebih besar apabila mereka membuat komunitas yang baik. Kekuatan dari banyak orang akan lebih mudah untuk mengubah hal dibandingkan dengan perseorangan. Desainer dapat melakukan perubahan dalam sustainable design apabile mereka bekerjasama untuk mencapai tujuan yang diinginkan. Selama ini, desainer hanya menganggap dirinya memiliki profesi sebagai seorang desainer, padahal mereka bisa lebih daripada apa yang dipikirkan. Oleh karena itu, desainer perlu melakukan perubahan bersama untuk desain berkelanjutan (Fitria, 2013).

\section{Sustainable Fashion}

Praktik sustainable design dapat diterapkan dalam hal yang lebih spesifik. Pada kesempatan ini, sustainable fashion (fashion berkelanjutan) menjadi topik spesifik yang akan dibahas. Sustainable fashion merupakan fashion mode yang mengedepankan nilai dari pihak yang terlibat, terutama dalam bidang lingkungan dan kemanusiaan. Tujuan dari sustainable fashion adalah menyatukan cara pandang desainer, produsen, distributor, hingga konsumen untuk bekerja sama untuk menyatukan pemikiran agar fashion dapat tergiring kea rah yang lebih baik mulai dari produksi hingga konsumsinya (Henninger et al., 2009; Kulsum, 2020) Beberapa teori Soviet berpendapat bahwa di mana ada kemajuan dalam sains dan teknologi ada kemajuan keindahan dalam fashion (Zhuk, 2016). 
Fashion menjadi penyumbang polusi terbesar kedua didunia setelah minyak. Konsumsi fast fashion berlangsung dengan sangat cepat, mulai dari produksi, hingga konsumsinya. Salah satu penyebabnya adalah ketika produk fashion hanya dipakai beberapa kali, lalu dibuang hanya karena perubahan tren fashion, atau lainnya. Sampah dari pembuangan produk fashion tersebut yang membuat menumpuknya limbah fashion (Angela et al., 2018).

Fashion merupakan hal yang penikmatnya semakin meningkat dari tahun ke tahun. Menurut Madelaine Ginsburg fashion adalah hal yang paling dihargai dari benda musium dan tidak pernah lebih popular dibanding sekarang (Petrov, 2019). Dengan semakin meningkatnya industry fashion dari waktu ke waktu, maka meningkat pula limbah yang dihasilkan oleh peminatnya.

Dalam praktiknya, sustainable fashion mengedepankan nilai-nilai nagi pihak yang terlibat, terutama lingkungan dan kemanusiaan. Tujuan sustainable fashion adalah untuk menyadarkan masyarakat mengenai ancaman yang dapat ditimbulkan jika menggunakan produk secara tidak ramah lingkungan. Kesadaran tersebut juga menjadi tanggung jawab industry fashion nirlaba untuk memberikan informasi yang akuran mengenaik hal-hal yang berhubungan dengan sustainable fashion, seperti perkerja, dampak lingkungan, upah, dan lainnya (Henninger et al., 2009; Kulsum, 2020)

Circular Economy (CE) juga dapat menjadi solusi dalam sustainable fashion. Dalam CE, bahan baku akan didaur ulang, dan juga menggunakan material yang ramah lingkungan untuk pembuatan fashion. Hal ini sudah diterapkan di beberapa negara. Mereka membuat fashion yang bahan bakunya dapat didaur ulang hingga 8 kali, sehingga cukup efektif untuk mengurangi limbah fashion (Niinimäki, 2018)

\section{Perilaku Belanja Produk Fashion pada lingkungan}

Pada era ini, cara hidup 'sekali pakai' telah membuat masyarakat dunia menjadi 'ambil-buat-pakaibuang'. Kecepatan konsumsi prodik menjadi 1,5 kali lipat dari apa yang bisa ditanggung oleh Bumi. Hal tersebut menjadi penyebab meningkatnya pemborosan, polusi dan emisi karbon. Sebanyak 92 juta ton limbah disebabkan oleh industry fashion setiap tahunnya dan diprediksi akan meningkat sebanyak 60\% antara 2015 dan 2030 (Mishra et al., 2020).
Fashion saat ini juga tidak hanya berfungsi sebagai kebutuhan sandang manusia, namun juga sebagai 'gaya hidup'. Peran fashion tidak hanya sekedar mode, namun juga berperan sebagai 'identitas'. Hal ini menjadikan masyarakat berpenampilan sesuai dengan bagaimana mereka ingin dipandang. Persepsi ini menimbulkan rasa tidak pernah puas dengan produk fashion yang telah dimiliki, sehinga orang akan terus-menerus membeli produk fashion baru apabila mereka melihat produk yang menggambarkan dirinya. Hal ini tentu bukan perilaku belanja yang baik dalam sustainable fashion (Zhuk, 2016)

Walaupun dalam beberapa tahun terakhir kesadaran masyarakat akan sustainable fashion sudah mulai meningkat, namun keputusan pembelian masih berdasarkan proteria, bukan kepentingan lingkungan. Namun, perusahaan fashion juga bertanggungjawab untuk mengedukasi konsumen bahwa kebiasaan bali, pakai, buang menimbulkan dampak negatif pada lingkungan (Mishra et al., 2020).

Mayoritas masyarakat yang mau mengeluarkan effort lebih untuk fashion adalah perempuas. Fashion dan feminism merupakan dua hal yang berjalan beriringan. Hal itu terjadi karena Wanita cukup memperhatikan penampilan dibandingkan dengan laki-laki. Nilai-nilai feminism tersebut juga mendukung pesatnya pertumbuhan fashion (Soetjipto \& Chandra, 2021).

Perilaku belanja masyarakat lain yang berdampak negatif pada lingkungan adalah pembelian implusif. Lagi-lagi perilaku tersebut didasari oleh ketertarikan sementara pada sebuah produk tanpa berpikir panjang. Kebanyakan masyarakat hanya mementingkan hiburan, kenikmatan, dan kesenangan saat belanja. Proses pembelian yang terburu-buru menyebabkan konsumen kurang memperhatikan kualitas produk sehingga menyesal setelahnya. Ditambah lagi dengan fashion yang selalu berubah trennya. Fashion bukanlah hal yang tetap, sehingga masyarakat banyak yang membeli produk fashion bukan hanya karena butuh, namun mengikuti tren. (Indah Suhartini \& Listyorini, 2011; Petrov, 2019).

Namun kita tidak bisa hanya focus terhadap perilaku belanja masyarakat. Kita juga harus memperhatikan material fashion. Dalam CE (ekonomi sirkular) produk fashion ada baiknya menggunakan material yang ramah lingkungan. Banyak dari material fashion memiliki resiko yang lebih tinggi dibandingkan material lain. Tekstil merupakan material yang cukup aman, namun tetap harus dikelola dengan baik (Nïnimäki, 2018). 


\section{Pembelian produk fashion yang berkualitas sebagai investasi pada lingkungan}

Perilaku belanja masyarakat yang kurang baik salah satu penyebabnya adalah kualitas. Pembelian implusif hanya ketertarikan sementara yang kurang berkualitas. Barang yang kurang berkualitas akan membuat produk tersebut mudah rusak dan akan membuat kecepatan konsumsi meningkat hingga memperbanyak limbah fashion. Selain implusif, pembelian barang yang kurang berkualitas disebabkan oleh harga produk yang murah. Harga produk yang murah identik dengan kualitas produk yang kurang baik. Hal tersebut sering dikatakan dengan 'ada harga ada barang', yang berarti kualitas produk sesuai dengan harga (Cook \& Yurchisin, 2017; Indah Suhartini \& Listyorini, 2011).

Mementingkan kualitas ketika membeli suatu produk merupakan langkah untuk menerapkan sustainable fashion karena dengan membeli barang berkualitas, kita dapat memperlambat laju konsumsi produk fashion hingga menjadi langkah awal untuk mengurangi limbah fashion yang ada. Hal itu terjadi karena barang yang berkualitas cenderung akan lebih awet dan membuat kita tidak perlu membeli produk baru dengan jangka waktu yang cepat (Cook \& Yurchisin, 2017; Indah Suhartini \& Listyorini, 2011).

Namun tidak semua masyarakat memiliki perilaku belanja yang sama. Cukup banyak pula masyarakat yang mementingkan kualitas ketika membeli sebuah produk. Mereka mau membeli barang mahal dengan persepsi barang tersebut memiliki kualitas yang lebih baik. Namun, tidak semua masyarakat yang membeli barang berkualitas menerapkan sustainable fashion. Banyak pula dari mereka yang membeli barang berkualitas namun tidak menunggu rusak untuk membeli produk baru. Apabila terdapat tren baru, mereka merasa juga harus membeli produk yang sedang tren tersebut. Hal ini berhubungan dengan industry fast fashion, yaitu dimanaperushaan menawarkan produk yang murah dan trendi namun sangat cepat berganti dengan produk lainnya. Fast fashion selalu ingin memenuhi kebutuhan pelanggan dan siklus perputaran produk hanya membutuhkan waktu yang sebentar. Sehingga orang akan membeli banyak barang dalam jangka waktu pendek dan limbah fashion yang semakin menumpuk (Cook \& Yurchisin, 2017; Nidia, Chanifathin; Suhartini, 2020)

\section{Simpulan}

Dari literatur di atas, dapat disimpulkan bahwa;

1. Perilaku belanja masyarakat yang mementingkan harga murah dibandingkan dengan kualitas dapat mempengaruhi lingkungan. Hal ini terjadi karena barang dengan kualitas yang kurang baik akan lebih cepat rusak dan hal tersebut dapat memperbanyak limbah sampah.

2. Kualitas baik pada produk fashion dibutuhkan untuk meminimalisir kerusakan dalam jangka pendek, sehingga orang tidak perlu membeli produk yang sama berulang kali.

3. Mengurangi limbah fashion cukup penting karena fashion termasuk limbah yang cukup berpengaruh besar dalam kerusakan bumi.

Saran untuk penelitian selanjutnya adalah perlunya tinjauan lebih dalam mengenai topik dan juga validasi jurnal yang digunakan, apakah jurnal tersebut dapat dipercaya atau tidak.

\section{Daftar Pustaka}

Angela, S., Karnadi, D. H., Sn, M., Renaningtyas, L., Ds, M., Petra, U. K., \& Siwalankerto, J. (2018). Perancangan Fotografi Fashion Sebagai Upaya Mengkritisi Dampak Negatif Fashion Terhadap Lingkungan Abstrak Pendahuluan Pembahasan Metode Perancangan Dalam proses pembuatan perancangan dibutuhkan.

Cook, S. C., \& Yurchisin, J. (2017). Fast fashion environments: consumer's heaven or retailer's nightmare? International Journal of Retail and Distribution Management, 45(2), 143-157. https://doi.org/10.1108/IJRDM-03-2016-0027

Fitria. (2013). Ruined by Design. In Journal of Chemical Information and Modeling (Vol. 53, Issue 9).

Hemmings, J. (2008). Sustainable fashion. In Fiberarts (Vol. 34, Issue 4). https://doi.org/ 10.4324/9781351058353-12

Henninger, C. E., Panayiota, J., \& Alevizou, C. J. O. (2009). What is sustainable fashion? Journal of Fashion Marketing and Management: An International Journal International Marketing Review International Journal of Retail \&amp; Distribution Management, 13(7), 279-296. https://doi.org/10.1108/13612020910957770

Indah Suhartini, Y., \& Listyorini, S. (2011). Pengaruh Shopping Lifetyle, Fashion Involvement, Dan Hedonic Shopping Motivation Terhadap Impulse Buying (Studi Kasus pada Konsumen Matahari Departement Store di Kota Semarang).

Kulsum, U. (2020). Sustainable Fashion as The Early Awakening of the Clothing Industry Post Corona Pandemic. International Journal of Social Science and Business, 4(3), 422-429. https://ejournal.undiksha.ac.id/index.php/IJSS $\mathrm{B} /$ index\%0ALOGO

Margolin, V. (2007). Design, the future and the human spirit. Design Issues, 23(3), 4-15. https://doi.org/10.1162/desi.2007.23.3.4 
Mishra, S., Jain, S., \& Malhotra, G. (2020). The anatomy of circular economy transition in the fashion industry. Social Responsibility Journal. https://doi.org/10.1108/SRJ-06-2019-0216

Nidia, Chanifathin; Suhartini, R. (2020). DAMPAK FAST FASHION DAN PERAN DESAINER DALAM MENCIPTAKAN Chanifathin Nidia Ratna Suhartini Abstrak. E-Journal, 09, 157166.

Niinimäki, K. (2018). Sustainable Fashion in a Circular Economy. Sustainable Fashion in a Circular Economy, 12-42.

Petrov, J. (2019). Fashion, History, Museums. In Fashion, History, Museums. https://doi.org/ 10.5040/9781350049024
Priyoga, I. (2010). Desain Berkelanjutan (Sustainable Design). Jurusan Teknik Arsitektur Fakultas Teknik Universitas Pandanaran, 8(1), 16-26.

Soetjipto, A., \& Chandra, A. (2021). Fashion, Feminisme dan Hubungan Internasional: Perdebatan dalam Literatur. Jurnal Ilmiah Hubungan Internasional, 17(1), 17-29. https://doi.org/10.26593/jihi.v17i1.4220.17-29

Zhuk, . I. (2016). Fashion Meets Socialism: Fashion Industry in the Soviet Union after the Second World War. In Journal of Social History. https://doi.org/10.1093/jsh/shv133 